DE PROPRIETATIBUS LITTERARUM

edenda curat

C. H. VAN SCHOONEVELD

Indiana University

Series Maior, 3 



\title{
STYLE
}

\section{The Problem and Its Solution}

\author{
by \\ BENNISON GRAY \\ University of Hawaii
}

1969

MOUTON

THE HAGUE - PARIS 
(C) Copyright 1969 in The Netherlands.

Mouton \& Co. N.V., Publishers, The Hague.

No part of this book may be translated or reproduced in any form, by print, photoprint, microfilm, or any other means, without written permission from the publishers.

Printed in The Netherlands by Mouton \& Co., Printers, The Hague. 